\title{
Re-aktualisasi Tato pada Iklan A Mild "You Will Figure It Out" dalam Membentuk Positioning Produk
}

\author{
Aisyi Syafikarani \\ Program Studi Magister Desain \\ Institut Teknologi Bandung
}

\begin{abstract}
Indonesia has a variety of cultures that produce works of art and one of them is a tattoo. The oldest tattoos in Indonesia are those owned by the Mentawai and Dayak tribes. But in its development the meaning of tattoos has been re-actualized into bad value. The shift in interpretation of tattoo stigma is used by A Mild to shape the positioning of its products in the minds of consumers. A Mild "You Will Figure it Out" took an extreme step, choosing to lift the identity of young minorities who were considered one eye, one of which was the character of a young tattooed person.

The ad visualization study will be analyzed using descriptive qualitative methods. The analysis will be divided into two stages, first stage is analyzing audio visual elements in advertisements, namely hear words, color, music, picture, seen words and movement. As well as analyzing filmic dramatiology with cinematographic theory which includes the camera's point of view, image size, lighting and settings. Then in the second stage, it is analyzing the shift of interpretation using the semiotic approach which refers to Roland Barthes's theory. Thus, this study can provide knowledge and insights about advertising and the development of design science, in the form of the application of analysis and criticism of the meaning in advertising, especially in the formation of product interpretation and positioning.
\end{abstract}

Keywords: tattoos, re-actualization, cigarettes, semiotics, advertising

\section{PENDAHULUAN}

Iklan rokok di luar negeri, khususnya Asia Tenggara sudah mulai berkurang setiap tahunnya. Hal ini didukung oleh ungkapan Direktur Eksekutif Aliansi Pengendalian Tembakau Asia Tenggara (SEATCA), Bungon Ritthiphakdee mengatakan bahwa seluruh negara - negara Asia Tenggara telah melarang total iklan tembakau di media cetak, televisi, radio dan film. Mereka juga menerapkan peringatan kesehatan bergambar pada kemasan rokok, yang terbesar adalah Thailand (85\% dibagian depan dan belakang) disusul Brunai Darussalam, Laos, dan Myanmar sebesar 75\%. Namun berbeda dengan Indonesia, Indonesia tidak dapat menghilangkan iklan rokok secara menyeluruh, sebagai gantinya iklan rokok di Indonesia diatur dalam perundangundangan.

Semenjak Juni 2014, para produsen rokok harus membatasi iklan dan promosi produk tembakau yang menjadi sponsor kegiatan. Pembatasan iklan ini diatur dalam Pasal 27 yang beberapa diantaranya berisi bahwa dalam film tidak boleh lagi ada katakata yang mengandung promosi rokok. Selain itu pada Pasal 29 juga dijelaskan mengenai peraturan pada media penyiaran, iklan produk tembakau hanya boleh ditayangkan setelah pukul 21.30 hingga pukul 05.00 pagi. Hal ini membuat pengiklan rokok harus 
mampu menyampaikan pesan dan makna kepada pemirsa dengan segala keterbatasan tersebut.

Seperti yang dilakukan PT HM Sampoerna Tbk dalam mengiklankan produk A Mild. HM Sampoerna adalah salah satu perusahaan rokok berskala nasional yang berkutat meraih pasar Indonesia.

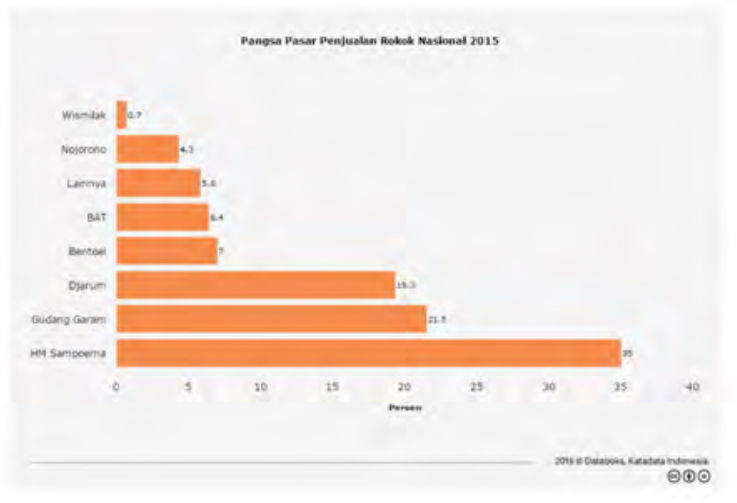

Gambar 1 Grafik pangsa pasar penjualan rokok Nasional 2015

Dari grafik tersebut dapat diketahui bagaimana HM Sampoerna pada tahun 2015 berhasil menjadi market leader dengan menguasai pangsa pasar sebesar 35\% dan salah satu produk dari HM Sampoerna yang memiliki tingkat mind share tinggi yaitu Sampoerna A Mild.

Di akhir tahun 1989, tepatnya pada tanggal 12 Desember 1989, HM Sampoerna membuat gebrakan dengan meluncurkan A Mild ke pasaran. Peluncuran ini menarik banyak perhatian dikarenakan produk A Mild sangat unik, yang tidak tergolong dalam kategori manapun dari ketiga kategori rokok yang ada pada saat itu yaitu sigaret kretek tangan (SKT), sigaret kretek mesin (SKM) reguler, dan sigaret putih mesin (SPM). A Mild merupakan suatu bentuk langkah berani yang telah diambil oleh HM Sampoerna untuk menciptakan kategori baru yaitu SKM Mild. Hal ini didukung pula oleh ungkapan Muhammad Warsianto, salah satu tokoh yang berperan dalam lahirnya A Mild mengatakan bahwa sejak awal A Mild memang sudah dirancang sebagai produk rokok yang tidak ada duanya di pasar domestik pada saat itu. Sehingga menjadikan A Mild sebagai pelopor, inovatif dan leader, seperti yang diungkapkan oleh Jiame J.M Liem, Marketing Manager HM Sampoerna.

Jika dilihat dari perkembangannya, A Mild adalah salah satu kategori rokok yang masih tetap bertahan selama 29 tahun walaupun banyak sekali pesaing. Pada tahun 2014 Sampoerna A Mild menjadi Top Brand produk rokok Mild dengan penjualan sebesar $53,3 \%$.

\begin{tabular}{|l|l|l|}
\hline ROKOK MILD & & \\
\hline Merek & TBI & TOP \\
\hline Sampoema A Mild & $53,3 \%$ & TOP \\
\hline Class Mild & $12,1 \%$ & TOP \\
\hline U mild & $6,7 \%$ & \\
\hline LA Light & $5,9 \%$ & \\
\hline Star Mild & $4,8 \%$ & \\
\hline
\end{tabular}

Gambar 2 Tabel Top Brand Produk Rokok Mild 2014

Namun dalam beriklan, produk rokok tidak hanya dibatasi dalam hal penayangan tetapi juga memiliki kendala lain yaitu dalam jangka panjang akan muncul permasalahan saat sebuah iklan dengan produk yang sama ditampilkan secara bersamaan. Apalagi produk rokok tidak memiliki Uniq Selling Proposition (USP) sehingga dalam beriklan 
mereka lebih menunjukkan keunikan konsep iklan. Maka untuk menghindari hal tersebut seorang produsen harus memiliki strategi kreatif yang tepat dalam mengiklankan produknya.

Pada tahun 2017, dapat dikatakan A Mild telah menjawab permasalahan tersebut, A Mild mengeluarkan campaign barunya yaitu A Mild "You Will Figure It Out". Pada iklan ini, A Mild melakukan pendekatan melalui pengguna dengan identitas dan gaya hidup mereka. Hal ini dikarenakan rokok bukanlah produk primer yang tanpanya kehidupan menjadi terganggu. Maka untuk mendapatkan dan mempertahankan konsumen sebesar-besarnya HM Sampoerna menjadikan "identitas" yang menjadi kebutuhan psikologis dasar manusia sebagai bahan dalam mempromosikan produknya. Hal ini dapat dilihat melalui visualisasi iklan yang dibuatnya seperti identitas anak muda yang bebas berekspresi dan berkarya dalam hal bermusik, visual art, hingga style. Dari sekian banyak visualisasi kebebasan berekspresi anak muda pada iklan tersebut, terdapat satu visualisasi yang cukup menonjol dan mengalami re-aktualisasi yaitu adanya beberapa scene yang menunjukkan sosok pemuda yang bertato.

Tato itu sendiri dapat dikatakan sebagai salah satu kebudayaan dan karya seni yang dimiliki Indonesia. Keberadaannya pun sudah ada semenjak nenek moyang jaman dahulu. Tato tertua yang ada di Indonesia adalah yang dimiliki oleh suku Mentawai dan Dayak. Pada zaman dahulu tato memiliki arti untuk menunjukkan jati diri dan perbedaan status sosial atau profesi. Selain itu tato juga dipercaya sebagai wujud penghormatan terhadap para leluhur, sebagai sarana dan simbol mengungkapkan penguasa alam, penangkal roh jahat serta mengusir penyakit maupun roh kematian. Namun dalam perkembangannya makna tato mengalami reaktualisasi menjadi bernilai buruk. Adanya program Petrus (penembakan misterius) pada tahun 1980-an, tato dinilai buruk dan diidentikkan dengan citra preman dan kriminal. Adanya pergeseran interpretasi mengenai stigma tato ini dimanfaatkan oleh A Mild untuk membentuk positioning produknya di benak para pemirsa. A Mild "You Will Figure it Out" mengambil langkah ekstrim, memilih untuk mengangkat identitas anak muda kaum minoritas yang dianggap sebelah mata, salah satunya yaitu karakter anak muda yang bertato.

Melihat fenomena yang telah diuraikan diatas penelitian ini dilakukan untuk menganalisa bagaimana makna tato pada iklan A Mild "You Will Figure It Out" dalam membentuk positioning produk.

\section{RUMUSAN MASALAH DAN TUJUAN PENELITIAN}

\section{Rumusan Masalah}

Bagaimana makna re-aktualisasi tato pada iklan A Mild "You Will Figure It Out" dalam membentuk positioning produk A Mild di benak para pemirsa?

\section{Tujuan Penelitian}

1. Menginterpretasikan tanda - tanda yang terkandung di balik visual tato pada iklan A Mild "You Will Figure It Out".

2. Mencari makna dari tanda di balik visual re-aktualisasi tato pada iklan A Mild "You Will Figure It Out" sehingga dapat membentuk positioning produk. 


\section{TEORI DAN METODE}

\section{Tato}

Dalam bahasa Indonesia, istilah tato disebut sebagai "rajah" yaitu menggambar kulit tubuh dengan alat tajam berupa jarum atau tulang, kemudian bagian tubuh yang digambar tersebut diberi zat pewarna atau pigmen warna-warni. Tato dianggap sebagai sebuah karya seni karena dalam proses tato terdapat kegiatan menggambar pola yang membentuk sebuah desain tato.

Di Indonesia jenis tato tertua dimiliki oleh suku Mentawai dan Dayak. Bagi suku Mentawai, tato merupakan roh kehidupan. Tato memiliki empat kedudukan, salah satunya yaitu menunjukkan jati diri dan perbedaan status sosial atau profesi. Selain itu tato bagi mereka juga memiliki fungsi sebagai simbol dari keseimbangan alam.

Sedangkan pada suku Dayak tato memiliki makna yang berbeda pula. Tato pada kebudayaan Dayak digunakan sebagai salah satu simbol dari kekayaan. Namun dibeberapa masyarakat Dayak seperti Dayak Iban dan Dayak Kayan juga meyakini bahwa tato merupakan wujud penghormatan kepada leluhur. Menato diyakini sebagai simbol dan sarana dalam mengungkapkan penguasa alam. Tato juga dipercaya sebagai penangkal roh jahat serta mampu mengusir penyakit ataupun roh kematian.

Indonesia sebagai salah satu negara yang memiliki kebudayaan asli tato pada akhirnya juga mengalami pergeseran. Bentuk dari pergeseran itu adalah tato tidak lagi memiliki muatan lokal dan sakral melainkan masuk ke dalam dunia fashion dan mode. Namun semenjak adanya program Petrus (Penembakan Misterius) pada tahun 1980-an, tato memiliki stigma yang buruk dan diidentikkan dengan perbuatan kriminal. Tato bercitra buruk yang dekat dengan gang, kekerasan, dan kejahatan. Dapat dikatakan bahwa orang bertato selalu meresahkan masyarakat. Sehingga seni tato ini menjadi dianggap tabu.

\section{Positioning}

Positioning adalah strategi komunikasi yang berhubungan dengan bagaimana khalayak menempatkan suatu produk atau merek di otaknya, di dalam alam khayalnya, sehingga khalayak memiliki penilaian tertentu. Hiebing dan Cooper, mendefinisikan positioning sebagai membangun persepsi produk di dalam pasar sasaran relatif terhadap persaingan (Morissan, 2012:73). Oleh sebab itu seorang pengelolah pemasaran harus mengetahui bagaimana konsumen memperoleh informasi, bagaimana konsumen menciptakan persepsi, dan bagaimana persepsi mempengaruhi pengambilan keputusan pembelian. Karena sekali informasi tersebut ditempatkan pada posisi yang salah, maka akan sulit untuk diubah.

Pernyataan positioning harus mampu mewakili citra atau persepsi yang hendak ditanamkan di benak konsumen. Biasanya pernyataan tersebut dapat berupa kata-kata yang diolah dalam bentuk rangkaian kalimat menarik yang disampaikan secara manis. Pernyataan yang dihasilkan harus singkat, mudah diulang-ulang dalam iklan, dan harus memiliki dampak yang kuat terhadap pasar sasarannya.

Dalam menyusun suatu positioning harus diketahui terlebih dahulu bagaimana audiensi membedakan produk bersangkutan dengan produk saingan yang lainnya. Mayers 
membedakan struktur persaingan ke dalam tiga tingkat yaitu: (Morissan, 2012:74)

- Superioritas

Suatu struktur persaingan yang dialami perusahaan atau produk yang unggul diberbagai bidang terhadap para pesaingnya.

- Diferensiasi

Pada tingkat diferensiasi ini suatu perusahaan bertindak lebih rasional yaitu tidak ingin unggul dalam segala hal, tetapi membatasi pada satu atau beberapa segi saja yang superior terhadap pesaing-pesaingnya.

- Program paritas

Disini perusahaan dan produknya sama sekali tidak dapat dibedakan satu sama lain. Hal ini membuat positioning menjadi lebih sulit ditentukan. Oleh sebab itu diciptakanlah pembeda khayalan dengan menanamkan citra merek, mengasosiasikan dengan tokoh-tokoh, humor, kantun, dan sebagainya. Dengan begitu suatu perusahaan atau suatu produk akan menjadi terlihat berbeda karena konsumen menganggap berbeda, bukan karena barang itu sendiri berbeda.

\section{Sinematografi}

Sinematografi sangat dibutuhkan dalam pembuatan iklan untuk mengkomunikasikan visual agar dapat mendukung isi pesan dan dramatisasi. Pembuatan film sangat berbeda dengan fotografi dikarenakan film merupakan objek yang begerak (Boggs dalam Dwitasari, 2011:26). Berikut merupakan teknis yang harus diperhatikan yaitu sudut pandang, ukuran gambar, pencahayaan, dan setting sebagai pembentuk makna gambar (Dwitasari, 2011:26).

\section{- Sudut Pandang}

Posisi kamera atau pengambilan sudut pandang yang mengarah pada obyek tertentu sangat berpengaruh pada makna dan pesan yang akan disampaikan (Bonafix, 2011:850). Sudut pengambilan gambar terdiri dari lima macam yaitu:

- Bird eye view adalah teknik pengambilan gambar yang dilakukan jauh diatas ketinggian obyek yang direkam. Teknik ini akan memberikan kesan luas karena menampilkan obyek-obyek yang sangat kecil. Selain itu bird eye juga digunakan untuk menyampaikan kesan lemah, sehingga penonton akan merasa iba dan tergerak hatinya (Bonavix, 2011:851)

- High angle adalah sudut pengambilan dari atas objek, akan tetapi lebih rendah dari bird eye. Sehingga akan memberikan kesan objek menjadi kecil, kerdil, dan tertekan.

- Low angle adalah pengambilan gambar dari bawah obyek yang akan memberikan kesan objek menjadi lebih besar sehingga akan muncul nilai dramatisasi keagungan, keunggulan, dan dominan.

- Eye level adalah pengambilan gambar yang sejajar dengan objek. Sudut pengambilan gambar ini yang paling sering digunakan. Namun sebenarnya sudut pengambilan gambar ini kurang memberikan kesan tertentu sehingga harus memperhatikan komposisi frame agar enak dilihat. Hasilnya akan memperlihatkan tatapan mata seseoang yang sejajar dan memiliki 
ketinggian yang sama dengan objek yang ditampilkan.

- Frog eye adalah teknik pengambilan gambar sejajar dengan posisi dasar dari objek untuk memberikan kesan objek menjadi sangat besar, mengerikan dan misteri. Selain itu juga akan memberikan kesan dramatis karena memperlihatkan suatu visual yang menarik tapi diambil dengan variasi tidak seperti biasanya.

\section{- Ukuran Gambar}

Ukuran gambar merupakan unsur penting untuk menunjukkan karakter, emosi, dan kondisi objek yang ingin disampaikan. Oleh karena itu juru kamera dituntut untuk memahami ukuran gambar sesuai dengan kebutuhan skenario sebuah adegan. Ukuran gambar yang bisanya digunakan yaitu:

- Extreme Close Up (ECU) adalah pengambilan gambar dari jarak yang sangat dekat sekali sehingga tekstur atau pori-pori kulit terlihat jelas. Fungsinya adalah memperlihatkan detail objek dengan jelas.

- Big Close Up (BCU) adalah pengambilan gambar dari kepala hingga sebatas dagu objek. Memiliki kesan menampilkan objek untuk menimbulkan ekspresi tertentu.

- Close Up (CU) adalah pengambilan gambar dari tepat atas kepala hingga leher bagian bawah. Fungsinya adalah untuk memberi gambaran objek secara jelas dengan ekspresinya.

- Medium Close Up (MCU) adalah ukuran gambar sebatas kepala hingga dada, dengan fungsi untuk memberikan kesan menegaskan profil seseorang.

- Waist shot/mid shot adalah ukuran gambar sebatas kepala hingga ke pinggang, berfungsi untuk menjelaskan objek dengan atribut yang lebih jelas.

- Medium Shot (MS) adalah ukuran gambar sebatas kepala hingga lutut, berfungsi untuk memperjelas gestur dan sedikit menggambarkan objek dengan latarnya.

- Full Shot (FS) artinya pengambilan gambar penuh dari atas kepala hingga kaki, berfungsi untuk menjelaskan objek dengan lingkungan sekitarnya.

- Long Shot (LS) yaitu pengambilan gambar yang lebih luas dari Full Shot, berfungsi untuk menunjukkan objek dengan latar belakangnya.

\section{- Pencahayaan}

Pengaturan pencahayaan pada sebuah film atau iklan berfungsi untuk memperkuat kesan dan pesan yang hendak disampaikan. Gaya pencahayaan terbagi menjadi empat yaitu: (Poland, 2015:16)

- High Key penataan cahaya dengan intensitas tinggi untuk memberikan kesan ringan, besih, keceriaan serta memberikan kesan positif. Sehingga akan menghasilkan visual secara jelas tanpa adanya bayangan. Biasanya high key digunakan dalam penayangan film komedi.

- Low Key penataan cahaya dengan intensitas rendah. Pada awalnya pencahayaan jenis ini digunakan pada teater, namun seiring berjalannya waktu juga digunakan dalam film dengan kontras yang tinggi dan bayangan gelap. Kesan yang ditimbulkan dari pencahayaan jenis ini yaitu memberikan kesan tegang, murung, depresi dan misterius.

- Available Light penataan cahaya hanya dengan memanfaatkan cahaya alami yang tersedia di lingkungan untuk menerangi 
tempat kejadian. Kesan yang dihasilkan dari pencahayaan ini yaitu kesan yang natural, jujur dan nyata.

- Combine Light yang merupakan gabungan antara beberapa jenis penggunaan cahaya.

\section{- Setting}

Setting adalah waktu dan tempat dimana sebuah cerita berlangsung. Setting akan memberikan penjelasan dari tema yang terdapat pada film. Selain itu setting juga dapat membentuk citra sebuah film. Kolaborasi dengan elemen dalam mendukung pembuatan film seperti kostum, pemeran, cerita dan lain-lain, membuat kegunaan setting menjadi sangat penting. Hal ini dikarenakan setting akan memberikan kesinambungan antara cerita dan citra dari sebuah film. Oleh sebab itu dibutuhkan pemikiran atau konsep yang khusus dalam pemilihan waktu, geografis, struktur sosial, ekonomi, adat istiadat, kebiasaan dan tingkah laku.

\section{Semiotika Roland Barthes}

Seorang filsuf, kritikus sastra, dan semiolog Prancis, Roland Barthes, meskipun juga penganut pandangan postrukturalis, ia juga merupakan orang yang paling eksplisit mempraktekkan semiologi Ferdinand de Saussure. Menurut Barthes sebuah bahasa membutuhkan kondisi tertentu untuk dapat menjadi mitos, yang secara semiotis dicirikan dengan hadirnya tataran signifikasi yang disebut sebagai sistem semiologis tingkat kedua (the second order semiological system), penanda-penanda berhubungan dengan petanda-petanda sedemikian sehingga menghasilkan tanda. Selanjutnya tanda-tanda pada tataran pertama ini akan menjadi penanda-penanda yang berhubungan pula dengan pertanda-pertanda pada tataran kedua. Pada tataran kedua inilah sebuah mitos bersarang. (Barthes dalam Budiman, 2011:38).

Aspek material mitos yang ada pada the second order semiological system dapat disebut sebagai retorik atau konotator-konotator yang tersusun dari tanda-tanda pada sistem pertama, sementara petanda-petandanya sendiri dapat dinamakan sebagai fragmen ideologi (Barthes dalam Budiman, 2011:38).

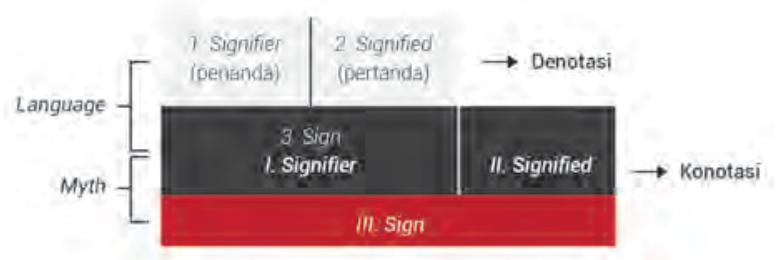

Gambar 3 Teori Semiotika Roland Barthes

Dalam tataran bahasa, yaitu sistem semiologis lapis pertama penanda-penanda berhubungan dengan petanda-petanda sedemikian sehingga menghasilkan tanda. Selanjutnya di dalam tataran mitos yakni sistem semiologis lapis kedua, tanda-tanda pada tataran pertama menjadi penandapenanda yang berhubungan lagi dengan petanda-petanda.

Barthes menggambarkan proses signifikasi berlapis ganda ini melalui perangkat konseptual yang lebih familiar yaitu denotasi dan konotasi (Budiman, 2011:39). Menurut Hjelmslev, lapisan pertama dalam tataran signifikasi menjadi wilayah denotasi dan lapisan kedua (yang ekstensif terhadap sistem pertama) menjadi wilayah konotasi (Undasmoro, 2007:82). 


\section{METODE}

Penelitian tentang re-aktualisasi tato dalam iklan A Mild "You Will Figure It Out" menggunakan pendekatan kualitatif deskriptif untuk mengetahui bagaimana reaktualisasi tersebut dikonstruksikan melalui elemen audio visual yang ditampilkan dengan cara mengkaji elemen audio, visual dan dramatologi film serta menangkap nilai kebebasan anak muda dalam berekspresi yang muncul ditinjau dari kebiasaan anak muda yang terjadi pada masyarakat Indonesia saat ini. Penelitian kualitatif digunakan karena mampu menganalisis realitas sosial secara mendalam.

Kajian visualisasi iklan akan dikupas dengan menggunakan metode analisis isi (content analysis). Analisis akan dibagi menjadi dua tahap, tahap pertama menganalisis elemen audio visual dalam iklan yakni heard words, color, music, picture, seen words dan movement. Serta menganalisis dramatologi film dengan teori sinematografi yang meliputi sudut pandang kamera, ukuran gambar, tata cahaya dan setting. Sehingga dapat disimpulkan bahwa pada tahap pertama bertujuan untuk mencari bagaimana kebebasan berekspresi anak muda bertato dikonstruksikan melalui elemen pembentuk iklan tersebut.

Kemudian ditahap kedua yakni menganalisis makna dari re-aktualisasi tato dengan menggunakan pendekatan semiotika yang mengacu pada teori Roland Barthes. Teori Barthes ini lebih menekankan pada makna dan pengembangan makna dari tanda itu sendiri. Sehingga pada tahap kedua ini akan diperoleh hasil perbandingan interpretasi mengenai tato pada jaman dahulu dan tato pada jaman sekarang yang ditampilkan pada iklan tersebut.

\section{Pembahasan Hasil Penelitian}

Iklan A Mild "You Will Figure It Out" berdurasi 60 detik. Iklan tersebut menampilkan segerombolan anak muda dengan kegemarannya yang terbagi menjadi menjadi lima identitas yaitu, anak punk, segerombolan freestyler sepeda dan skateboard, segerombolan anak muda dengan penampilan yang nyentrik, beberapa orang yang berkecimpung di dunia musik seperti penyanyi, disk jokey (DJ), breakdance dan clubbing, serta seorang visual art yang sedang membuat graffiti. Dari kelima identitas tersebut terdapat satu identitas yang cukup menonjol yaitu terdapat sosok anak punk yang bertato. Scene tersebut terdapat pada detik 00:04-00:05, 00:05-00:06， 00:08-00:09, dan 00:58-00:60. Tahap analisis pada visualisasi tersebut akan terbagi menjadi dua tahap. Tahap pertama analisis elemen audio visual serta dramatologi film. Kemudian pada tahap kedua yaitu analisis makna dengan teori semiotika Roland Barthes.

\section{Analisis Tahap 1}

Visual 1

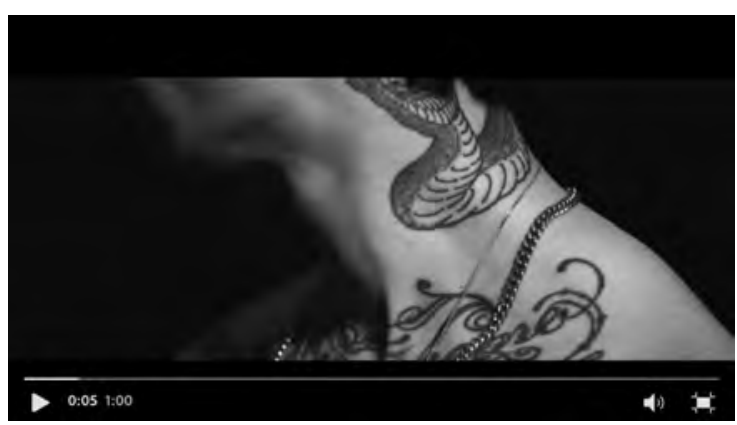

Gambar 4 Visual 1 (00:04-00:05)

Dramatologi Film

- Sudut pandang: Eye level 
- Ukuran gambar: Extreme close up

- Pencahayaan: Low key

- Setting: Dalam studio

Elemen Audio Visual

- Model: Pria bertato

- Benda: Kalung rantai

- Warna: Cenderung gelap

- Gerak/Interaksi: Model terlihat dari sisi samping

- Seen word: -

- Jingle: Beat cepat, suara drum

Visual 2

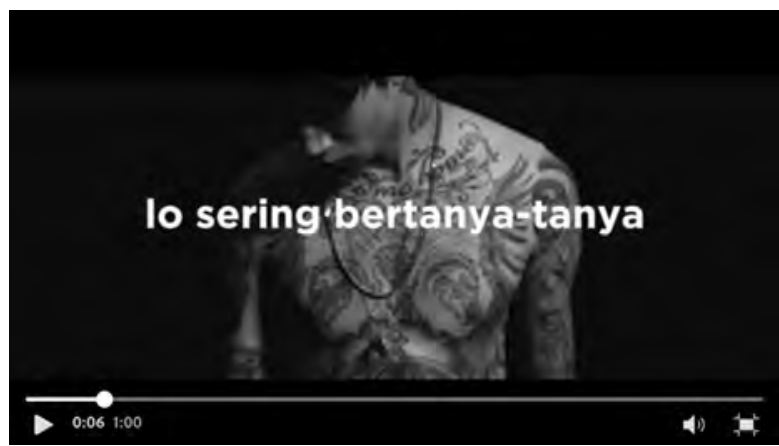

Gambar 5 Visual 2 (00:05-00:06)

Dramatologi Film

- Sudut pandang: Eye level

- Ukuran gambar: Waist shot/mid shot

- Pencahayaan: Low key

- Setting: Dalam studio

Elemen Audio Visual

- Model: Pria bertato

- Benda: Kalung rantai

- Warna: Cenderung gelap

- Gerak/Interaksi: Model menunduk

- Seen word: Lo sering bertanya-tanya

- Jingle: Musik dengan beat cepat dan suara drum

Visual 3

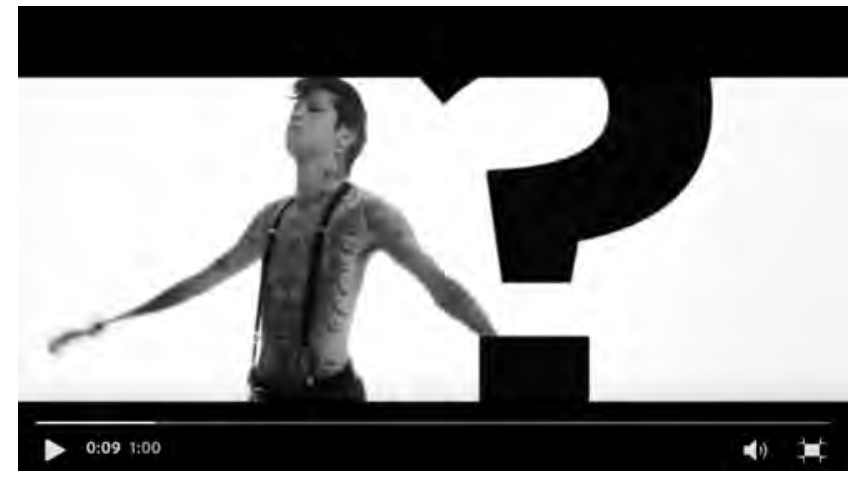

Gambar 6 Visual 3 (00:08-00:09)

Dramatologi Film

- Sudut pandang: Eye level

- Ukuran gambar: Waist shot/mid shot

- Pencahayaan: High key

- Setting: Dalam studio

Elemen Audio Visual

- Model: Pria bertato

- Benda: Kostum celana dan suspender

- Warna: Terang

- Gerak/Interaksi: Model terlihat dari sisi samping

- Seen word: ?

- Jingle: Musik dengan beat cepat dan suara drum

Visual 4

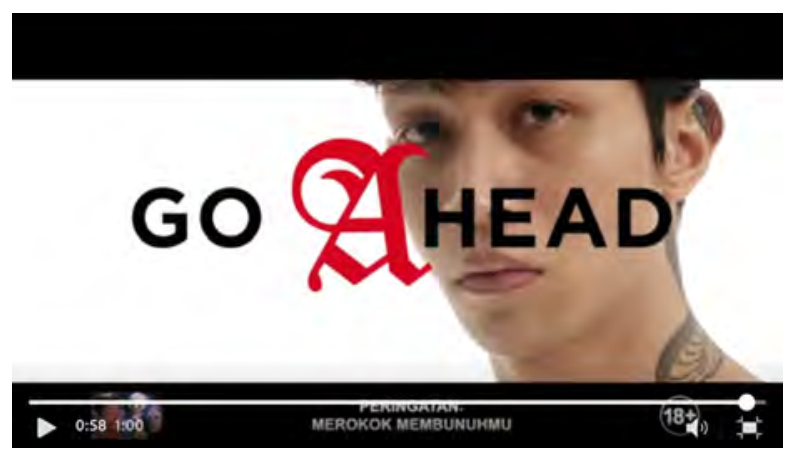

Gambar 7 Visual 4 (00:58-00:60)

Dramatologi Film

- Sudut pandang: Eye level

- Ukuran gambar: Big close up

- Pencahayaan: High key 
- Setting: Dalam studio

Elemen Audio Visual

- Model: Pria bertato

- Benda: -

- Warna: Terang

- Gerak/Interaksi: Memandang tajam ke depan

- Seen word: Nanti Juga Lo Paham

- Jingle: Rapper dengan beat semakin cepat

\section{Kesimpulan Analisis Tahap 1}

Dapat disimpulkan bahwa pada visual 1 dan 2 dari segi dramatologi film, kedua visual tersebut menggunakan sudut pandang eye level dengan pencahayaan yang minimum sehingga kesan yang muncul yaitu visual yang gelap dan cenderung berwarna hitam. Sedangkan dari segi elemen audio visual, kedua visual tersebut lebih menunjukkan interaksi model, dimana ia berdiri sendiri dan menunduk. Kemudian terdapat seen word "lo sering bertanya-tanya”.

Hal yang kontras terjadi pada visual 3 dan 4. Dari segi dramatologi film, visual sosok pria bertato tersebut tidak lagi menggunakan pencahayaan yang minimum, melainkan high level sehingga kesan yang ditimbulkan lebih terlihat cerah dan bersih. Selain itu dari segi elemen audio visual, visual 3 dan 4 lebih menunjukkan interaksi model yang menatap tajam kearah depan dan terdapat seen word berupa tanda tanya besar “?”.

Analisis Tahap 2
Analisis pada tahap 2 ini menggunakan teori semiotika Roland Barthes yang terbagi menjadi makna denotasi dan konotasi.

- Makna denotasi

Pada visual 1 dan 2 memperlihatkan sosok pria dengan style punk yang seluruh tubuhnya bertato. Orang dengan tubuh yang bertato dianggap buruk dan dipandang sebelah mata (Syafikarani, 2017). Hal ini didukung dengan sejarah yang berkembang jaman dulu. Tato dibuat untuk maksud dan tujuan tertentu, akan tetapi semenjak rezim Orde Baru di Nusantara tato dipandang sebelah mata. Operasi pemberantasan preman pada tahun 1980-an menandai para kriminal dengan ciri fisik tubuh bertato dan berambut gondrong (Prasetyo, 2017). Dengan gaya Orde Baru yang sangat represif, stigma dapat dengan cepat menyebar dan mengakar bahkan hingga saat ini.

Pada scene ini terlihat pria tersebut merasa sendiri dan terasingkan. Hal ini didukung dengan dramatologi film, dimana pencahayaan yang digunakan yaitu low key yang merepresentasikan kemurungan (Poland, 2015), begitu juga dominasi warna yang digunakan yaitu hitam yang berarti keputusasaan (Nugroho, 2015). Interaksi yang terlihat pada visual 2 yaitu posisi pria yang menunduk. Hal ini mengartikan bahwa pria tersebut kurang percaya diri, depresi dan tertekan. Selain itu juga terdapat seen word yang muncul yaitu "lo sering bertanyatanya.." yang merepresentasikan bahwa orang tersebut merasa bingung dan bertanya-tanya apakah yang salah dengan dirinya. Sehingga dapat disimpulkan bahwa pada scene ini merepresentasikan anak punk bertato yang 
merasa terasingkan dan putus asa karena tidak diterima oleh lingkungannya.

Berbeda lagi pada visual 3 dan 4, kedua visual ini tetap memperlihatkan sosok pria bertato namun dengan suasana yang berbeda. Visual ini lebih menunjukkan kesan perubahan dan berani. Didukung dengan dramatologi film, dimana pencahayaan yang digunakan yaitu high key yang merepresentasikan kesan ringan, besih, keceriaan serta memberikan kesan positif (Poland, 2015). Interaksi pria tersebut yang menatap ke arah depan pada visual 4, turut memperkuat penyampaian pesan dari pria tersebut bahwa ia tidak lagi depresi atau terasingkan melainkan ia berubah menjadi sosok yang berani. Seen word berupa "?" tanda tanya merupakan penyampaian pesan kepada pemirsa mengenai "apa masalahnya jika mereka berbeda?". Begitu juga seen word "Go A Head" yang menyampaikan pesan bahwa meskipun banyak yang meremehkan mereka. Mereka tidak berhenti untuk memamerkannya dan terus berpikir positif."

Secara tersirat pada lapis pertama makna denotasi dapat disimpulkan bahwa Iklan ini mengajak audiens untuk berani bebas dalam berekspresi tanpa harus takut pandangan negatif orang. Mereka juga mencoba untuk mengajak audiens memahami apa yang mereka lakukan. Mereka ingin menyampaikan bahwa tidak selamanya hal yang dianggap negatif itu berdampak buruk karena terkadang hal-hal tersebut merupakan sebuah media untuk mereka dalam berkarya.

\section{- Makna konotasi}

Secara denotatif, iklan ini tidak hanya mengajak audiens untuk terus berkarya. Namun jika diperdalam secara konotatif ternyata iklan ini melakukan pergeseran pandangan terhadap identitas anak muda jaman sekarang. Identitas yang muncul pada iklan tersebut jika dilihat dari sudut padang konvensi yang berlaku menampilkan karakter-karakter yang dianggap tidak baik. Akan tetapi A Mild memanfaatkan paradigma tersebut untuk membentuk positioning produknya. A Mild mencoba untuk memperbaiki paradigma tersebut, bahwa tidak selamanya hal yang dianggap negatif itu buruk. Karena terkadang melalui hal-hal tersebut seseorang dapat berekspresi dan berkarya. Seperti fenomena tato. Tidak selamanya tato memiliki stigma yang buruk karena terkadang melalui tato para anak muda dapat mengekspesikan dirinya melalui desain gambar yang dibuatnya.

Selain itu dengan konsep ini, jika dianalisis lebih dalam lagi A Mild tidak hanya menunjukkan bahwa mereka mewadahi dan menganggap keberadaan mereka yang terdiskriminasi (kaum minoritas) melainkan lebih dalam lagi yaitu mencoba menetapkan standar baru bahwa anak muda dalam menyalurkan ekspresinya tidak hanya mereka yang berekspresi sesuai dengan konvensi atau nilai yang berkembang dimasyarakat, misalnya mengeskpresikan dirinya yang macho, petualang atau seorang eksekutif muda. Tetapi mereka yang dianggap buruk pun memiliki kebebasan dalam berekspresi tanpa harus meninggalkan hal yang disukainya.

\section{Kesimpulan Analisis Tahap 2}

Dapat disimpulkan bahwa iklan A Mild "You Will Figure It Out" pada visual sosok pria bertato terbagi menjadi dua yaitu visual 1 dan 2 yang menunjukkan bagaimana pria tersebut merasa diasingkan, tato masih 
dianggap memiliki stigma yang buruk. Sedangkan pada visual 3 dan 4 menunjukkan adanya perubahan, bahwa pria bertato tersebut juga bebas dalam mengekpresikan dirinya. Disinilah re-aktualisasi dari tato tersebut direpresentasikan dalam iklan.

\section{KESIMPULAN}

A Mild seri "You Will Figure it Out". Sampoerna mengambil langkah yang ekstrim dengan memilih untuk mengangkat tema semangat against the stream tentang kebebasan berekspresi dengan menggeser atau bahkan mengubah interpretasi tentang identitas anak muda yang berada pada titik normal (dianggap baik) di masyarakat pada umumnya. Pergeseran tersebut dapat dilihat dari visualisasi pada visual 1 dan 2 yang menunjukkan bagaimana masyarakat menganggap negatif dari tato. Kemudian pada akhir iklan yaitu pada visual 3 dan 4 menampilkan tentang re-aktualisasi dari tato. Mereka mencoba untuk menggeser atau melakukan pembaruan nilai-nilai kehidupan yang telah melekat di masyarakat. Iklan ini mencoba untuk mengembalikan makna dari tato, tato tidak selamanya memiliki nilai yang negatif, tetapi tato dapat dijadikan sebagai media dalam mengekspresikan diri melalui desain tato yang dibuatnya.

A Mild memanfaatkan konsep reaktualisasi tato tersebut untuk membentuk positioning produknya sebagai produk yang berbeda dari yang lainnya, ia mencoba memposisikan produknya sebagai produk pelopor dan leader, tiada duanya. Disaat produk rokok yang lainnya muncul dengan identitas anak muda yang memiliki nilai positif, A Mild muncul dengan konsep iklan yang meminjam pandangan negatif masyarakat terhadap sebuah fenomena seperti tato. Dan diakhir iklan ia mencoba untuk mere-aktualisasi fenomena tersebut. Selain itu dengan konsep ini, jika dianalisis lebih dalam lagi A Mild tidak hanya menunjukkan bahwa mereka mewadahi dan menganggap keberadaan mereka yang terdiskriminasi (kaum minoritas) melainkan lebih dalam lagi yaitu mencoba menetapkan standar baru bahwa anak muda dalam menyalurkan ekspresinya tidak hanya mereka yang berekspresi sesuai dengan konvensi atau nilai yang berkembang dimasyarakat, misalnya mengeskpresikan dirinya yang macho, petualang atau seorang eksekutif muda. Tetapi mereka yang dianggap buruk pun memiliki kebebasan dalam berekspresi tanpa harus meninggalkan hal yang disukainya. Dengan demikian A Mild menjadi produk rokok yang terlihat berbeda dengan merek rokok Mild lainnya.

Dari penelitian ini dapat memberikan pengetahuan dan wawasan mengenai iklan serta pengembangan ilmu desain, berupa penerapan analisis dan kritik terhadap makna dalam iklan terutama dalam pembentukan interpretasi dan positioning produk.

\section{DAFTAR PUSTAKA}

\section{Buku}

[1] Budiman, Kris. (2011): Semiotika Visual. Konsep, Isu, dan Problem Ikonisitas. Yogyakarta : Jalasutra

[2] Bonafix, D. N. (t.thn.). Videografi: Kamera dan Teknik Pengambilan Gambar. Jurusan Desain Komunikasi Visual, Fakultas Komunikasi dan Multimedia, BINUS University.

[3] Dwitasari, Putri. (2011): Konstruksi dan Budaya Kecantikan dalam Iklan Media Televisi (Studi Kasus Iklan Pond's White 
Beauty Tahun 2001-2010). Tesis Program Magister Institut Teknologi Bandung.

[4] Morissan, M. (2010). Periklanan, Komunikasi Pemasaran Terpadu. Jakarta: Kencana Prenada Media Group.

[5] Nugroho, S. (2015). Manajemen Warna dan Desain. Yogyakarta: ANDI.

[6] Ogilvy, D. (1983). Ogilvy on Advertising. London: Pan Book.

[7] Pease, A. (1996). Bahasa Tubuh, Bagaimana Membaca Pikiran Seseorang Melalui Gerak Isyarat. Jakarta: Arcan.

[8] Poland, J. L. (2015). Light, Camera, Emotion an Examination on Film. Bachelor of Science in Aducation, Kent State Univercity.

[9] Syafikarani, A. (2017). Kajian Komunikasi Dibalik Makna Campaign A Mild "Nanti Juga Lo Paham". International Symposium ARCADESIA (hal. 397). Yogyakarta: ISI Yogyakarta.

[10] Udasmoro. (2007): Petualangan Semiologi. Yogyakarta : Pustaka Pelajar.

[11] Widiariputri, Dinda Alita. Sejarah Tato dan Gambaran Umum Perempuan Bertato. Skripsi Universitas Erlangga. Surabaya.

\section{Situs Internet}

[1] Asean Larang Iklan Rokok Kecuali Indonesia. Diperoleh melalui situs: https://www.antaranews.com/berita/64253 0/asean-larang-iklan-rokok-kecualiindonesia. Diunduh pada tanggal 28 Oktober 2018

[2] Goaheadpeople Challenge, Diperoleh melalui situs internet: https://www.goaheadpeople.id/. Diunduh pada tanggal 2 Mei 2018

[3] Iklan A Mild Nanti Juga Lo Paham 60s, diperoleh melalui situs internet: https://www.youtube.com/watch?v=PfJ1
y8GR2bc. Diunduh pada tanggal : 3 Februari 2018.

[4] Ini Aturan Pembatasan Iklan Rokok yang Harus Dipatuhi Juni

[5] 2014. Diperoleh melalui situs: https://www.liputan6.com/health/read/48 5628/ini-aturan-pembatasan-iklan-rokokyang-harus-dipatuhi-juni-2014. Diunduh pada tanggal 28 Oktober 2018

[6] Memahami Gerak Kepala Lawan Bicara. Diperoleh dari situs internet: https://www.suara.com/lifestyle/2014/04/2 9/073357/memahami-arti-gerakan-kepalalawan-bicara. Diunduh pada tanggal 3 November 2018.

[7] Sampoerna Kuasai 35 Persen Pangsa Rokok Nasional. Diperoleh dari situs internet:

https://databoks.katadata.co.id/datapublis h/2016/08/23/sampoerna-kuasai-35persen-pangsa-rokok-nasional. Diunduh pada tanggal : 2 Mei 2018

[8] Tabel Top Brand 2014. Diperoleh dari situs internet: http://www.topbrandaward.com/ Diunduh pada tanggal : 25 Mei 2018

[9] Tato dan Mengapa Dia Dicap Buruk.. Diperoleh dari situs internet: https://kumparan.com/@kumparanstyle/ta to-dan-mengapa-dia-dicap-buruk. Diunduh pada tanggal 3 November 2018 